ҚАЗАҚСТАН РЕСПУБЛИКАСЫ

ҰЛТТЫҚ ҒЫЛЫМ АКАДЕМИЯСЫНЫН

АБАЙ АТЫНДАҒЫ ҚАЗАҚ ҰЛТТЫҚ

ПЕДАГОГИКАЛЫҚ УНИВЕРСИТЕТІНІҢ

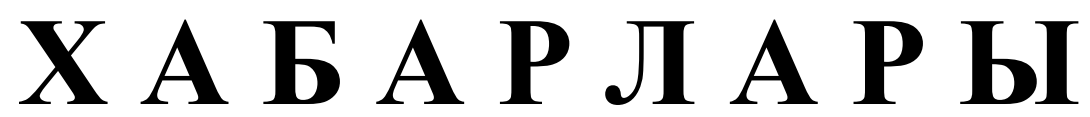

\section{ИЗВЕСТИЯ}

НАЦИОНАЛЬНОЙ АКАДЕМИИ НАУК РЕСПУБЛИКИ КАЗАХСТАН

КАЗАХСКИЙ НАЦИОНАЛЬНЫЙ

ПЕДАГОГИЧЕСКИЙ УНИВЕРСИТЕТ ИМ. АБАЯ

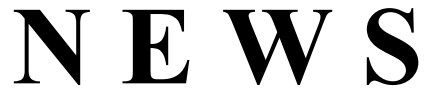

OF THE NATIONAL ACADEMY OF SCIENCES OF THE REPUBLIC OF KAZAKHSTAN

ABAY KAZAKH NATIONAL PEDAGOGICAL UNIVERSITY

ҚОҒАМДЫҚ ЖӘНЕ ГУМАНИТАРЛЫҚ ҒЫЛЫМДАР СЕРИЯСЫ

СЕРИЯ ОБЩЕСТВЕННЫХ И ГУМАНИТАРНЫХ НАУК

SERIES OF SOCIAL AND HUMAN SCIENCES

\author{
6 (322) \\ ҚАРАША - ЖЕЛТОҚСАН 2018 ж. \\ НОЯБРЬ - ДЕКАБРЬ 2018 Г. \\ NOVEMBER - DECEMBER 2018 \\ ИЗДАЕТСЯ С ЯНВАРЯ 1962 ГОДА \\ PUBLISHED SINCE JANUARY 1962 \\ ЖЫЛЫНА 6 РЕТ ШЫҒАДЫ \\ ВЫХОДИТ 6 РАЗ В ГОД \\ PUBLISHED 6 TIMES A YEAR
}

1962 ЖЫЛДЫҢ ҚАНТАР АЙЫНАН ШЫҒА БАСТАҒАН 
Ба с ре дактор

ҚР ҰҒА кұрметті мүшесі

Балықбаев Т.O.

Р е д а ц и я а лқ а сы:

экон. ғ. докторы, проф., ҚР ҰҒА академигі Баймұратов У.Б.; тарих ғ. докторы, проф., ҚР ҰҒА академигі Байпақов К.М.; филос. ғ.докторы, проф., ҚР ҰҒА академигі Есім Г.Е.; фил. ғ. докторы,, проф., ҚР ҰҒА академигі Қирабаев С.С.; эк. ғ. докторы, проф., ҚР ҰҒА академигі Кошанов А.К.; эк.ғ. докторы, проф., ҚР ҰҒА академигі Нәрібаев К.Н. (бас редактордың орынбасары); филос. ғ.докторы, проф., ҚР ҰҒА академигі Нысанбаев А.Н.; заң ғ. докторы, проф., ҚР ҰҒА академигі Сәбікенов С.Н.; заң ғ. докторы, проф., ҚР ҰҒА академигі Сүлейменов М.К.; эк. ғ. докторы, проф., ҚР ҰҒА академигі Сатыбалдин С.С.; тарих ғ. докторы, проф., ҚР ҰҒА академик Әбжанов Х.М.; тарих ғ. докторы, проф., ҚР ҰҒА корр. мүшесі Әбусеитова М.Х.; тарих ғ. докторы, проф., ҚР ҰҒА академик Байтанаев Б.А.; филол. ғ. докторы, проф., ҚР ҰҒА корр. мүшесі Жақып Б.А.; фил. ғ. докторы, проф., академик НАН РК Қалижанов У.К.; филол. ғ. докторы, проф., ҚР ҰҒА академик Қамзабекұлы Д.; тарих ғ. докторы, проф., ҚР ҰҒА академик Қожамжарова Д.П.; тарих ғ. докторы, проф., ҚР ҰҒА академик Койгелдиев М.К.; фил. ғ. докторы, проф., ҚР ҰҒА корр. мүшесі Кұрманбайұлы Ш.; тарих ғ. докторы, проф., ҚР ҰҒА корр. мүшесі Таймағанбетов Ж.К.; социол. ғ. докторы, проф., ҚР ҰҒА корр. мүшесі Шәукенова 3.К.; фил. ғ. докторы, проф., КР ҰҒА корр. мүшесі Дербісәлі А.; саяси. ғ. докторы, проф., Бижанов А.К., тарих ғ. докторы, проф., Кабульдинов 3.Е.; фил. ғ. докторы, проф., ҚР ҰҒА корр мүшесі Қажыбек Е.3.

\section{Р едакция ке н е с i:}

Молдова Республикасының ҰҒА академигі Белостечник Г. (Молдова); Әзірбайжан ҰҒА академигі Велиханлы Н. (Азербайджан); Тәжікстан ҰҒА академигі Назаров Т.Н. (Тәжікстан); Молдова Республикасының ҰҒА академигі Рошка А. (Молдова); Молдова Республикасының ҰҒА академигі Руснак Г. (Молдова); Әзірбайжан ҰҒА корр. мүшесі Мурадов Ш. (Әзірбайжан); Әзірбайжан ҰҒА корр. мүшесі Сафарова 3. (Әзірбайжан); э. ғ. д., проф. Василенко В.Н. (Украина); заң ғ. докт., проф. Устименко В.А. (Украина)

«Қазақстан Республикасы Ұлттық ғылым академиясының Хабарлары. Қоғамдық және гуманитарлық ғылымдар сериясы». ISSN 2224-5294

Меншіктенуші: «Қазақстан Республикасының Ұлттық ғылым академиясы» РҚБ (Алматы қ.)

Қазақстан республикасының Мәдениет пен ақпарат министрлігінің Ақпарат және мұрағат комитетінде 30.04.2010 ж. берілген № 10894-Ж мерзімдік басылым тіркеуіне қойылу туралы куәлік

Мерзімділігі: жылына 6 рет.

Тиражы: 500 дана.

Редакцияның мекенжайы: 050010, Алматы қ., Шевченко көш., 28, 219 бөл., 220, тел.: 272-13-19, 272-13-18, http://nauka-nanrk.kz. social-human.kz

(C) Қазақстан Республикасының Ұлттық ғылым академиясы, 2018

Типографияның мекенжайы: «Аруна» ЖК, Алматы қ., Муратбаева көш., 75. 
Главный редактор

Почетный член НАН РК

T.O. Балыкбаев

Р е дак ци онн а я коллег и я:

докт. экон. Н., проф., академик НАН РК У.Б. Баймуратов; докт. ист. н., проф., академик НАН РК К.М. Байпаков; докт. филос. Н., проф., академик НАН РК Г.Е. Есим; докт. фил. Н., проф., академик НАН РК С.С. Кирабаев; докт. экон. Н., проф., академик НАН РК А.К. Кошанов; докт. экон. Н., проф., академик НАН РК К.Н. Нарибаев (заместитель главного редактора); докт. филос. н., проф., академик НАН РК А.Н. Нысанбаев; докт. юр. Н., проф., академик НАН РК С.Н. Сабикенов; докт. юр. н., проф., академик НАН РК М.К. Сулейменов; докт. экон. Н., проф., академик НАН РК С.С. Сатубалдин; докт. ист. н., проф., академик НАН РК Х.М. Абжанов; докт. ист. н., проф., чл.-корр. НАН РК М.Х. Абусеитова; докт. ист. н., проф., академик НАН РК Б.А. Байтанаев; докт. фил. н., проф., чл.-корр. НАН РК Б.А. Жакып; докт. фиолол. н., проф., академик НАН РК У.К. Калижанов; докт. фил. н., проф., академик НАН РК Д. Камзабекулы; докт. ист. н., проф., академик НАН РК Д.П. Кожамжарова; докт. ист. н., проф., академик НАН РК М.К. Койгельдиев; докт. филол. н., проф., чл.-корр. НАН РК Ш. Курманбайулы; докт. ист. н., проф., чл.корр. НАН РК Ж.К. Таймаганбетов; докт. социол. н., проф., чл.-корр. НАН РК З.К. Шаукенова; д. филол. н., проф., чл.-корр. НАН РК А. Дербисали; доктор политических наук, проф., Бижанов А.К.; доктор ист. наук, проф., Кабульдинов 3.Е.; доктор филол. н., проф., член-корр. НАН РК Қажыбек Е.3.

Р е дак ци онны й с ов ет

академик НАН Республики Молдова Г. Белостечник (Молдова); академик НАН Азербайджанской Республики Н. Велиханлы (Азербайджан); академик НАН Республики Таджикистан Т.Н. Назаров (Таджикистан); академик НАН Республики Молдова А. Рошка (Молдова); академик НАН Республики Молдова Г. Руснак (Молдова); чл.-корр. НАН Азербайджанской Республики Ш. Мурадов (Азербайджан), член-корр. НАН Азербайджанской Республики 3.Сафарова (Азербайджан); д. э. н., проф. В.Н. Василенко (Украина); д.ю.н., проф. В.А. Устименко (Украина)

Известия Национальной академии наук Республики Казахстан. Серия общественных и гуманитарных наук. ISSN 2224-5294

Собственник: РОО «Национальная академия наук Республики Казахстан» (г. Алматы)

Свидетельство о постановке на учет периодического печатного издания в Комитете информации и архивов

Министерства культуры и информации Республики Казахстан № 10894-Ж, выданное 30.04.2010 г.

Периодичность 6 раз в год

Тираж: 500 экземпляров

Адрес редакции: 050010, г. Алматы, ул. Шевченко, 28, ком. 219, 220, тел. 272-13-19, 272-13-18, www:nauka-nanrk.kz / social-human.kz

(C) Национальная академия наук Республики Казахстан, 2018 г.

Адрес типографии: ИП «Аруна», г. Алматы, ул. Муратбаева, 75

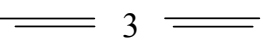


Chief Editor

\section{Honorary member of NAS RK \\ Balykbayev T.O}

Editorial board:

Doctor of economics, prof, academician of NAS RK Baimuratov U.B.; doctor of history, prof, academician of NAS RK Baipakov K.M.; doctor of philosophy, prof, academician of NAS RK Esim G.E.; doctor of philology, prof, academician of NAS RK Kirabayev S.S.; doctor of economics, prof, academician of NAS RK Koshanov A.K.; doctor of economics, prof, academician of NAS RK Naribayev K.N. (deputy editor-in-chief); doctor of philosophy, prof, academician of NAS RK Nyssanbayev A.N.; doctor of law, prof, academician of NAS RK Sabikenov S.N.; doctor of law, prof, academician of NAS RK Suleymenov M.K.; doctor of economy, prof, academician of NAS RK Satybaldin S.S.; doctor of history, prof, academician of NAS RK Abzhanov H.M; doctor of history, prof, corresponding member of NAS RK Abuseitova M.H.; doctor of history, prof, academician of NAS RK Baitanaev B.A.; doctor of philology, prof, corresponding member of NAS RK Zhakyp B.A.; doctor of philology, prof, academician of NAS RK Kalizhanov U.K.; doctor of philology, prof, academician of NAS RK Hamzabekuly D.; doctor of history, prof, academician of NAS RK Kozhamzharova D.P.; doctor of history, prof, academician of NAS RK Koigeldiev M.K.; doctor of philology, prof, corresponding member of NAS RK Kurmanbaiuly Sh.; doctor of history, prof, academician of NAS RK Taimaganbetov J.K.; doctor of sociology, prof, corresponding member of NAS RK Shaukenova Z.K.; doctor of philology, prof, corresponding member of NAS RK Derbisali A.; doctor of political science, prof Bizhanov A.K; doctor of History, prof Kabuldinov Z.E.; doctor of philology, prof, corresponding member of NAS RK Kazhybek E.Z.

\section{Editorial staff:}

Academician NAS Republic of Moldova Belostechnik.G (Moldova); Academician NAS Republic of Azerbaijan Velikhanli N. (Azerbaijan); Academician NAS Republic of Tajikistan Nazarov T.N. (Tajikistan); Academician NAS Republic of Moldova Roshka A. (Moldova) Academician NAS Republic of Moldova Rusnak G. (Moldova); Corresponding member of the NAS Republic of Azerbaijan Muradov Sh. (Azerbaijan); Corresponding member of the NAS Republic of Azerbaijan Safarova Z. (Azerbaijan); Associate professor of Economics Vasilenko V.N. (Ukraine), Associate professor of Law Ustimenko V.A. (Ukraine)

News of the National Academy of Sciences of the Republic of Kazakhstan. Series of Social and Humanities. ISSN 2224-5294

Owner: RPA "National Academy of Sciences of the Republic of Kazakhstan" (Almaty)

The certificate of registration of a periodic printed publication in the Committee of information and archives of the Ministry of culture and information of the Republic of Kazakhstan N 10894-Ж, issued 30.04.2010

Periodicity: 6 times a year

Circulation: 500 copies

Editorial address: 28, Shevchenko str., of. 219, 220, Almaty, 050010, tel. 272-13-19, 272-13-18, www:nauka-nanrk.kz / social-human.kz

(C) National Academy of Sciences of the Republic of Kazakhstan, 2018

Address of printing house: ST "Aruna", 75, Muratbayev str, Almaty 
N E W S

OF THE NATIONAL ACADEMY OF SCIENCES OF THE REPUBLIC OF KAZAKHSTAN

SERIES OF SOCIAL AND HUMAN SCIENCES

ISSN 2224-5294

Volume 6, Number 322 (2018), 146 - 150

https://doi.org/10.32014/2018.2224-5294.46

UDC 631.16

K.M. Zhakisheva, D.T. Zhumanova, G.M. Mukasheva

Kazakh Agrotechnical University. S.Seifullin,

kuralay_zhakisheva@mail.ru,dzhumanova@mail.ru, gulzhan74@mail.ru

\title{
THE ROLE OF MONITORING THE FINANCIAL CONDITION OF AGRICULTURAL ENTERPRISES IN ENSURING SUSTAINABLE DEVELOPMENT OF THE AGRARIAN SECTOR OF THE ECONOMY
}

\begin{abstract}
According to the authors, the financial sustainability of agricultural enterprises only when the level of income of the organization exceeds its level of expenditure. The role of monitoring increases as an organization is capable of allowing unjustified receivables and payables, tax liabilities, does not pay its obligations on time, is able to bear unforeseen losses without any consequences, and does not support the competitiveness of its products in the market. Financial stability is identified with solvency, financial independence, profitability, liquidity. In domestic and foreign literature there is no unequivocal interpretation of the concept of "financial sustainability of an enterprise." It is interpreted differently. The authors gave their own definition, while examining the points of view of various authors, the financial stability of an organization should be understood as a state of financial resources that ensures self-financing of replicated costs and solvency.
\end{abstract}

Keywords: agriculture, export, potential, competition, financial monitoring, forecasting, business, sustainable development.

\section{INTRODUCTION}

In the context of globalization and the increasing uncertainty of the market environment, the problem of ensuring the sustainability of organizations is of particular relevance. A feature of market relations is fierce competition, inflation, technological changes. In these conditions, an organization faces the problem of rational organization of financial activities for its further prosperity and ensuring the stability of its financial condition.

\section{MAIN PART}

So, I.O. Cherkasova believes that the financial stability of an enterprise is determined by the efficient formation, distribution and use of financial resources [1,174 p].

V.A. Rusak and N.A. Rusak write that financial sustainability "is characterized by financial independence, the ability to maneuver with its own means, sufficient financial security for the uninterrupted operation of the main types of activities, and the state of production potential [2,116 p].

V.M. Rodionov and M.A. Fedotov give the following definition: "The financial sustainability of an enterprise is the state of financial resources, their distribution and use, which ensures the development of an enterprise based on the growth of profits and capital while maintaining solvency and creditworthiness, under the conditions of acceptable level of risk "[3.13 p].

Given the uncertainty of the market environment, the most appropriate definition of the concept was given by A.V. Endovitskaya and L.T. Gilyarovskaya: "The financial sustainability of any business entity is the ability to carry out basic and other activities under conditions of business risk and a changing business environment in order to maximize the welfare of owners, strengthening the competitive advantages of the organization, taking into account the interests of society and the state [4]. 
Financial sustainability is the key to survival and the basis for the stability of the organization's position [5.187 p.]. On the stability of the organization have, both internal and external factors.

To the internal:

- state and structure of the property;

- structure of products, its share in total effective demand;

-the size and structure of expenses, their ratio to cash incomes;

-material, financial and labor resources of the enterprise.

-competence and professionalism of the managers of the organization, the ability to respond to changes in the internal and external environment, etc.

To external include:

- economic conditions of management;

- prevailing technology and technology in society;

-payment of consumer demand;

-degree of development of insurance and foreign economic relations;

-the adjustment of economic relations with partners

- tax and credit policy of the state;

-industry organization and others.

There are a lot of methods for determining financial stability, there are also a number of indicators on the basis of which one can determine the financial position of an enterprise.

The task of financial stability analysis is to assess the size and structure of assets and liabilities.

The analysis of financial stability on a particular date allows you to answer the question: how well did the organization manage financial resources during the period preceding this date. The state of financial resources must meet the requirements and meet the goals of the organization's development. Insufficient financial stability can lead to insolvency and to the insolvency of the organization, and excessive financial stability impedes the development of the organization, facilitates the freezing of funds and the formation of excess reserves. Therefore, an important task of the analysis is the study of indicators characterizing financial stability $[6,136 \mathrm{p}]$.

The indicators characterizing the independence for each element of the assets of the enterprise and for the property as a whole, make it possible to measure whether the company is financially stable enough.

Having studied the points of view of various authors, it can be done that the financial stability of an organization should be understood as a condition of financial resources that ensures self-financing of replicated costs and solvency.

The characteristic of financial stability includes the analysis:

- the composition and distribution of assets of an economic entity;

- dynamics and structure of sources of financial resources;

- availability of own current assets;

- payables; receivables; solvency.

Financial sustainability is estimated based on absolute and relative indicators.

Absolute indicators characterize the degree of security of the sources of their formation.

In the process of the enterprise, its reserves are constantly replenished through the use of working capital and borrowed funds (various loans and borrowings). In order to find out the sources that form the reserves, you need to have information about the availability of your own money from the company, about the availability of sources from which the company takes borrowed funds. It is necessary to take into account the size of the main sources from which the reserves are formed (own sources of financing, shortcomings or excess working capital, the amount of these sources of coverage).

To characterize the sources of formation of stocks determine the three main indicators:

1) the presence of own working capital;

2) availability of own and long-term borrowed sources of formation of stocks;

3 ) the total value of the main sources of formation of stocks. 
In the process of analyzing the sources of formation of assets of an enterprise, it is necessary to establish the actual amount of own and borrowed funds, their share in total capital, analyze the composition and structure of borrowed funds in the context of short-term and long-term sources of formation of assets of an enterprise, analyze the composition and structure of short-term and long-term liabilities.

The three indicators of the availability of sources of formation correspond to three indicators of the availability of stocks and sources of their formation:

1) surplus or lack of working capital;

2) excess or lack of own and long-term sources of formation of stocks;

3) surplus or shortage of the total amount of main sources of formation.

The calculation of these indicators allows you to classify the financial situation of the organization according to the degree of its stability into the following four types:

1. The absolute financial stability of the enterprise is a high solvency, which means that the entire debt of the organization can be covered from working capital, while not dependent on external loans. This situation is not perfect, it makes it clear that the management of enterprises is not able or does not want to use external sources of sources.

2. Normal financial stability of the enterprise is a normal solvency and efficient production activities. In this case, the company uses long-term borrowed funds. This financial stability becomes the most acceptable for the organization.

3. Unsustainable financial situation is a violation of solvency, which with the help of borrowed loans, reducing receivables, increasing inventory turnover, makes it possible to restore the balance.

4. Crisis financial condition means that the enterprise is almost bankrupt. Cash, receivables, other assets do not even cover accounts payable and overdue loans. In accordance with the Law of the Republic of Kazakhstan dated March 7, 2014 No. 176-V "On Rehabilitation and Bankruptcy", bankruptcy is an insolvency of a debtor recognized by a court decision, which is the basis for its liquidation. In order to prevent such a situation, financial stability is determined by the company on an ongoing basis monitoring of financial stability. This is a prerequisite for the life of any enterprise in crisis conditions (both large, medium and small).

Along with the absolute indicators of the stability of the financial situation of the organization is characterized by a system of relative indicators - financial ratios. The analysis of financial ratios consists in comparing their values with basic values, as well as in studying their dynamics over the reporting period and over several years. The main indicators giving material for analysis, in this case are: the coefficients of financing, financial independence. Also, this includes the ratio of security of own funds and the coefficient of their maneuverability, the coefficient of mobility of property, the ratio of investment coverage.

The financing ratio shows the extent to which the assets of the enterprise are formed at the expense of equity, and how independent the organization is from external sources of financing. If the value is less than one, then this may indicate a risk of insolvency.

The financial independence ratio shows the share of an organization's assets, which are covered by its own capital. The higher the ratio, the more likely the organization can pay off debts at its own expense. The higher the score, the more independent the enterprise.

The ratio of own sources of financing shows what part of current assets is financed at the expense of own funds. The recommended value of the coefficient of security with its own sources of financing is greater than 0.6-0.8. The smaller the value of the coefficient, the more unstable the financial condition of the organization.

The basis of financial stability is considered the rational use of working capital. To improve the financial condition of the company, it is necessary to carefully monitor and manage receivables, monitor the quality and ratio.

Receivables acts as a source of repayment of accounts payable of the enterprise. If the company will freeze amounts in settlements with customers and customers, it may feel a shortage of funds, leading to

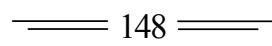


the formation of payables, late payments to the budget, social insurance and security payments, wage arrears and other payments. This in turn will entail the payment of fines, penalties and forfeits.

\section{CONCLUSION}

Late payment for products to suppliers and violation of contractual obligations will lead to loss of business reputation of the company and ultimately to insolvency and illiquidity. Analyzing the liquidity of the balance sheet, they compare the state of liabilities and the state of assets, which makes it possible to assess the degree of the organization's readiness to pay off its debts.

Therefore, to improve the financial condition, an enterprise should monitor the ratio of receivables and payables.

In a narrower sense, the financial stability of an economic entity is its financial condition, in which it has solvency, liquidity and has sufficient funds for normal functioning.

If an enterprise is financially stable, then it has an advantage over other enterprises of the same profile in attracting investments, in obtaining loans, in choosing suppliers and in selecting qualified personnel.

Finally, it does not conflict with the state and society, since it pays taxes to the budget in a timely manner, contributions to social funds, wages to workers and employees, dividends to shareholders, and guarantees banks repayment of loans and interest on them. The higher the stability of the enterprise, the more it is independent of an unexpected change in market conditions and, consequently, the lower the risk of being insolvent.

\section{REFERENCES}

[1] 1.Cherkasov I.O. Analysis of economic activity. St. Petersburg: Neva Publishing House, 2003. 192 p.

[2] Rusak V.A., Rusak N.A. Financial analysis of business entities: reference book, Graduate School, 1997. 309 p.

[3] Rodionova V.M., Fedotova M.A. The financial stability of the enterprise in terms of inflation. M: Publishing house "Perspective", 1995. 98s.

[4] Gilyarovskaya L.T., Endovitskaya A.V. Analysis and evaluation of the financial sustainability of commercial organizations - M: UNI-TI-DANA, 2006. $159 \mathrm{p}$.

[5] Fauzer V.V., Bochkova S.V. Analysis of the financial sustainability of the organization: theory questions: Sykt GU, 2007. 300 p.

[6] 6.Dyusembaev K.Sh. Analysis of financial statements: Textbook .- Almaty: Economics, 2009. 366 p.

[7] Sabirova R.K., The foreign experience features of labor market regulation /. International Journal of Experimental Education / № 4 for 2014 (part 1) pp. 81-82 in English ISSN 1996-3947. RINC -0.048 (In English)

[8] Zhansagimova A.E. Food Security of Kazakhstan. Reports of NAS RK, No. 2, 2016, p.219. http://reportsscience.kz/index.php/en/archive DOI https://doi.org/10.32014/2018.2518-1483

\section{К.М. Жакишева, Д.Т. Жуманова, Г.М. Мукашева}

Казахский агротехнический университет им. С.Сейфуллина

\section{РОЛЬ МОНИТОРИНГА ФИНАНСОВОГО СОСТОЯНИЯ СЕЛЬСКОХОЗЯЙСТВЕННЫХ ПРЕДПРИЯТИЙ В ОБЕСПЕЧЕНИИ УСТОЙЧИВОГО РАЗВИТИЯ АГРАРНОГО СЕКТОРА ЭКОНОМИКИ}

Аннотация. По мнению авторов, финансовая устойчивость аграрных предприятий только тогда, когда уровень доходов организации превышает уровень ее расходов. Роль мониторинга возрастает так, как организация способна допустить неоправданную дебиторскую и кредиторскую задолженности, задолженности по налоговым обязательствам, не расплачивается по своим обязательствам в срок, в состоянии без каких либо последствий переносить непредвиденные убытки, не поддерживать на рынке конкурентоспособность своей продукции. Финансовую устойчивость отождествляют с платёжеспособностью, финансовой независимостью, прибыльностью, ликвидностью. В отечественной и зарубежной литературе нет однозначного толкования понятия «финансовая устойчивость предприятия» - трактуется по разному. Авторами дано 
собственное определение, при этом исследовав точки зрения различных авторов, под финансовой устойчивостью организации следует понимать такое состояние финансовых ресурсов, при котором обеспечиваются самофинансирование воспроизведенных затрат и платежеспособность.

Ключевые слова: сельское хозяйство, экспорт, потенциал, конкуренция, финансовый мониторинг, прогнозирование, бизнес, устойчивое развитие

УДК 631.16

\section{К.М. Жакишева, Д.Т. Жуманова, Г.М. Мукашева}

С.Сейфуллин атындағы Қазақ агротехникалық университеті

\section{ЭКОНОМИКАНЫН АГРАРЛЫК СЕКТОРЫНЫН ТҰРАКТЫ ДАМУЫНА АРНАЛҒАН АУЫЛ ШАРУАШЫЛЫК КӘСІПОРЫНДАРЫНЫН ҚАРЖЫЛЫҚ ШАРТТАРЫН МОНИТОРИНГІНІҢ РӨЛІ}

Аннотация. Авторлардың пікірінше, ұйымның табыс деңгейі оның шығындар деңгейінен асқан жағдайда ғана ауыл шаруашылық кәсіпорындарының қаржылық тұрақтылығы. Мониторингтің рөлі ұйымның негізсіз дебиторлық және кредиторлық берешектерге, салықтық міндеттемелерге, өз міндеттемелерін уақытында төлеуге, қандай да бір зардаптарсыз күтпеген шығындарға шыдай алатынына және нарықтағы өз өнімдерінің бәсекеге қабілеттілігін қолдауға қабілетсіз болғандықтан, артады. Қаржылық тұрақтылық төлем қабілеттілігі, қаржы тәуелсіздігі, кірістілік, өтімділікпен анықталады. Отандық және шетелдік әдебиеттерде «кәсіпорынның қаржылық тұрақтылығын» тұжырымдамасын біржақты түсіндіру жоқ. Ол әртүрлі түсіндіріледі. Авторлар түрлі авторлардың көзқарастарын қарастыру кезінде өздерінің анықтамасын берді, ұйымның қаржылық тұрақтылығы репликтелген шығындар мен төлем қабілеттілігін өздігінен қаржыландыруды қамтамасыз ететін қаржы ресурстарының жағдайы ретінде түсінуге тиіс.

Түйін сөздер: ауыл шаруашылығы, экспорт, потенциал, бәсекелестік, қаржылық мониторинг, болжау, бизнес, орнықты даму

Information about authors:

Zhakishev Kuralay Muratovna - PhD doctoral student KATHU them. S. Seifullin, Republic of Kazakhstan, Astana city, Pobeda Ave., 62, https://orcid.org/0000-0002-3857-6860;

Zhumanova Dametken Tokenovna - candidate of economic Sciences, associate Professor of the Department "Finance" KATU them. S. Seifullin, Republic of Kazakhstan, Astana city, Pobeda Ave., 62, https://orcid.org/0000-0002-4762-3235;

Mukasheva Gulzhan Muratbekovna - master of economic Sciences, senior lecturer, Kazakh agrotechnical University. S. Seifullin, Republic of Kazakhstan, Astana city, Pobeda Ave., 62, https://orcid.org/0000-0002-3020-6144 


\section{МАЗМҰНЫ}

Беспаева Р.С., Бугубаева Р.О., Мануэль Ф. Грела2. Көрсеткіштердің теңдестірілген жүйесі негізінде Щучинск-Бурабай курорттық аймағын дамытудың кешенді стратегиясын қалыптастыру ................................................................................ 5

Аюпова 3.К., Құсайынов Д.Ө.Азаматтық процесстерді жетілдірудегі интеграцияның кейбір қырлары...................... 13

Құсайынова А. А., Вальдемар Козловски, Геращенко И. П.Қазақстан республикасындағы міндетті әлеуметтік сақтандырудың қаржылық-құқықтық тетіктерінің ерекшеліктері.

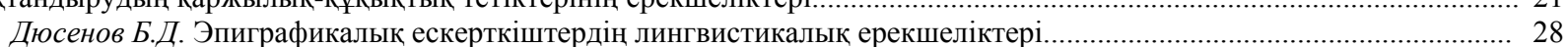

Джумадилова Ш.Г., Атабай Б.Ж. Қазақстандағы халықтың жинақтарының динамикасы......................................... 33

Карабалина А.А., Альситова А. Б., Кереймаганбетова Ж.Н., Абишева Н. М. Құндылық - рухани-адамгершілік

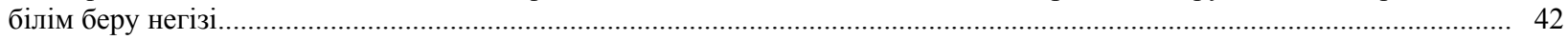

Кенжебаева Д.К., Өрмөрза Б. Ғ., Дашгин Махаммадли. Қазақстандық заманауи жастардың құндылығы............. 51

Нурманова А.Ш., Медерова Д.Е., Дюсенов Б.Д. «Бөкейхан әулетінің талдыбейіт қорымы» эпиграфикалық ескерткіштері тарихи дереккөз ретінде.

Кыдырова Ж.Ш., Онласынов Е.З., Абишова А.У., Шадиева А.А. Оңтүстік Қазақстан облысы сүт және сүт өнімдері нарығындағы жағдайды зерттеу ......

Абимова Г.У., Аманжолов Р., Мынбаева Б.Н., Ибрагимова Д.И. ЖОО-да биолог-студенттердің жобаларды

ұйымдастырылуы мен орындалуына даярлығы.......

Балтабаева А.Ю., Ризаходжаева Г. Мәдени интеграция үдерісіндегі жібек жолының феномені............................... 9

Бурганова Р.И., Абдугалина С.Е., Туякова А.Е. Студенттерге бағытталған білім беру арқылы білім сапасын

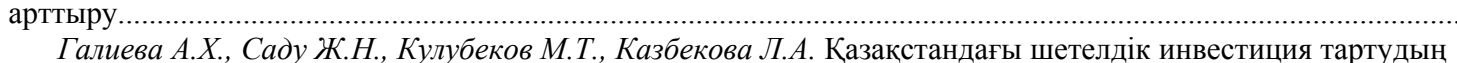

институционалдық жағдайын (талаптарын) бағалау..

Джалилов 3.Г., Батырхан Б.Ш. ХX ғ. екінші жартысындағы шетелдік исламтанушылардың ислам және саясат

туралы теориялық дискурсы.......

Джумабекова А.Т., Канатова А.Ж. Қаржылық ынтымақтастық жағдайларындағы Қазақстан республикасының

ұлттық банкінің өткізу механизмінің өзгеруі......

Дүйсен Г. М., Айтжанова Д. А. Қазақстан және Орталық Азия елдеріндегі көші-қон процесстері дамуының мәселелері мен ерекшеліктері

Есендұлова М.Н. Қазақстандағы « Қиын балаларды» оңалтудың және әлеуметтендірудің психологиялық ерекшеліктері

Жакишева К.М., Жуманова Д.Т., Мукашева Г.М. Экономиканың аграрлық секторының тұрақты дамуына арналған ауыл шаруашылық кәсіпорындарының қаржылық шарттарын мониторингінің рөлі.....

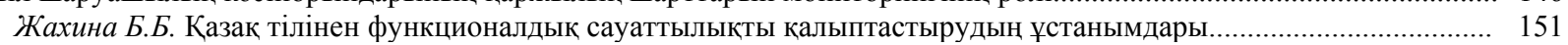

Идресова У.Х., Садуахасова 3.Ж., Муханова А.Т. Криминалистика....................................................................... 156

Савельева В. В. Қазақстандағы кредит технологиясын пайдалану және дамуының тарихи және педагогикалық базасы.

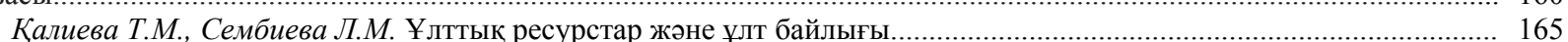

Каримова Р.У., Хаджиева Г.У. ҚХР Ұлттық саясаты контексіндегі ШҰАА-ның этносаяси және әлеуметтікэкономикалық трансформациясы мәселесі.

Керімбек Г., Молдашбаева Л., Джрауова Қ., Ажмухамедова А., Мизанова А. Қазақстан республикасының

республикалық бюджетіне түсетін салық түсімдерінің көрсеткіштерін талдау және бағалау.....

Жолдасбекова С.А., Парманкулова П.Ж., Асаналиев М.К. Мүмкіндігі шектеулі балаларды дамытудағы ұлттық ойындар

Молдакенова Е.К., Байгабулова К.К., Онаева Б.Т. БҚО-да инновациялық үрдістерді басқарудың аймақтық

аспектілігі жүйесінің дамудың жолдары.

Мұратова Г.К., Шаушенова А.Г., Жумасеитова С.Д., Онұварбаева М.Б.Білім беру үрдісінде бұлттық

технологияларын қолдану......

Несіпбеков E. Н., Аппакова Г.Н. Кәсіпорынның инвестициялық портфелін қалыптастырудың теориялық

Нургабылов М.Н., Барлыков Е.К., Егембердиева С.М. ҚР есеп өнеркәсібінің дамуының басқаруының трендсі....... 220

Нурымбетов Т.Я., Абишова А.У., Уразбаева Г.Ж., Кыдырова Ж.Ш., Байнеева П.Т., Абишо Н.У. Модернизациялық

жағдайындағы қр халқын әлеуметтік қолдауының басымдықтары.....

Рахимова С. А., Тургумбекова М. М. Қазақстан республикасындағы шағын және орта бизнестіңмемлекеттік қолдау

бағдарламалары және олардың тиімділігін жүзеге асыру шаралары.......................................................................... 233

Руденко Е.И. Орталық пен Оңтүстік Азия мемлекеттері арасындағы ұғынудың бұрмалануы - «Жұмсақ күш»

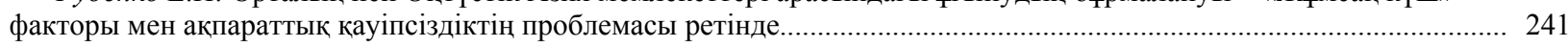

Тохтабаева Ш. Қазына-сандық.......................................................................................................... 251

Утепкалиева К.М., Сабирова Р.К., Кенбаева Г.У. Мұнай-газ секторындағы мемлекеттік-жеке серіктестікті дамыту

Мыңбаев Д. Е. Банкте басқару есебін ұйымдастыру тұжырымдамасы...

Султанова Г.С. Жаңа формацияның экономисі - бакалаврдың кәсіби құзыреттілігін қалыптастырудың

Шаяхметова А.А. Университет жағдайында инклюзивті білім беру үшін педагогтарды оқыту....... 


\section{СОДЕРЖАНИЕ}

Беспаева Р.С., Бугубаев Р.О., Мануэль Ф. Грела. Формирование комплексной стратегии развития ЩучинскоБоровской курортной зоны на основе сбалансированной системы показателей. Аюпова 3.К., Кусаинов Д.У., Уинстон Наган. Некоторые грани интеграции в совершенствовании гражданского процесса.

Кусаинова А.А., Козловски Вальдемар, Геращенко И.П. Обзор некоторых особенностей финансово-правового механизма обязательного социального страхования в республике Казахстан......

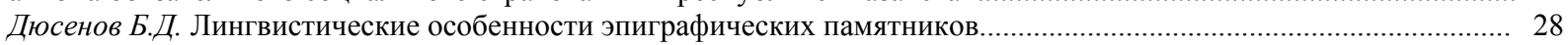

Джумадилова Ш.Г., Атабай Б.Ж.Динамика сбережений населения в Казахстане................................................... 33

Карабалина А.А., Альситова А. Б., Кереймаганбетова Ж.Н., Абишева Н. М. Ценность как базовая основа духовнонравственного образования.

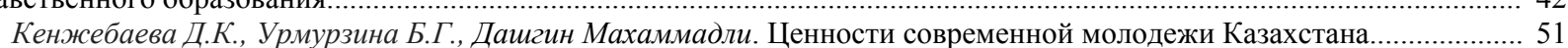

Нурманова А.Ш., Медерова Д.Е., Дюсенов Б.Д. Эпиграфические памятники «Некрополи талдыбейит династии

Бокейхановых» как исторический источник.

Кыдырова Ж.Ш., Онласынов Е.З., Абишова А.У., Шадиева А.А.Исследование ситуации на рынке молока и молочной продукции южно-казахстанской области

Абишова Г.У., Аманжолов Р., Мынбаева Б.Н., Ибрагимова Д.И. Готовность студентов-биологов к организации

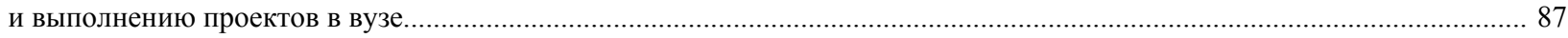

Балтабаева А.Ю., Ризаходжаева Г. Феномен великого шелкового пути в процессе культурной интеграции............... 91

Бурганова Р.И., Абдугалина С.Е., Туякова А.Е. Повышение качества образования посредством

студентоцентрированного обучения...

Галиева А.Х., Саду Ж.Н., Кулубеков М.Т., Казбекова Л.А. Оценка институциональных условий привлечения

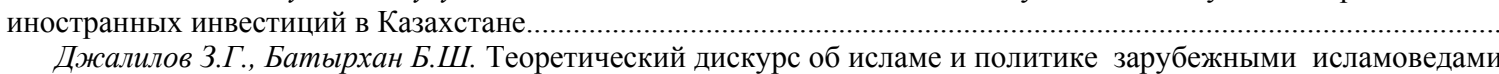
второй половины ХX в.

Джумабекова А.Т., Канатова А.Ж. Трансформация трансмиссионного механизма национального банка республики

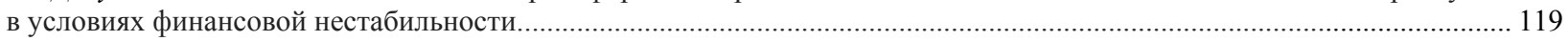

Дуйсен Г.М., Айтжанова Д.А. Проблемы и особенности развития миграционных процессов в Казахстане

и странах Центральной Азии.

Есенгулова М.Н. Психологические особенности реабилитации и социализации "Трудных подростков"

в Казахстане".

Жакишева К.М., Жуманова Д.Т., Мукашева Г.М.Роль мониторинга финансового состояния сельскохозяйственных

предприятий в обеспечении устойчивого развития аграрного сектора экономики.........................................................146

Жахина Б.Б. Принципы формирования функциональной грамотности казахского языка.......................................... 151

Идресова У.Х., Садуахасова 3.Ж., Муханова А.Т. Криминалистика......................................................................... 156

Савельева B.B. Исторические и педагогические основы формирования и разработки кредитной технологии

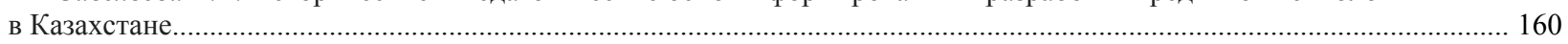

Калиева Т.М., Сембиева Л.М. Национальные ресурсы и богатство нации.................................................. 165

Каримова Р.У., Хаджиева Г.У. К вопросу об этно-политической и социально-экономической трансформации

СУАР в контексте национальной политики КНР

Керимбек Г., Молдашбаева Л., Джрауова Қ., Ажмухамедова А., Мизанова А. Анализ и оценка показателей

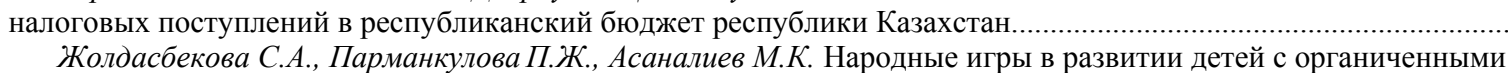

Жолдасбекова С.А., Парманкулова П.Ж., Асаналиев М.К. Народные игры в развитии детей с органиченными

Молдакенова Е.К., Байгабулова К.К., Онаева Б.Т.Пути развития системы регионального аспекта управления

инновационными процессами в АПК.

Муратова Г.К., Шаушенова А.Г., Жумасеитова С.Д., Онгарбаева М.Б. Применение облачных технологий

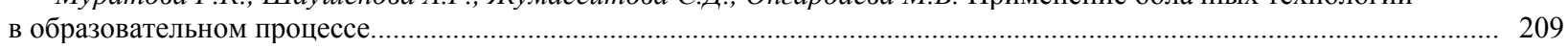

Несипбеков Е.Н., Аппакова Г.Н. Теоретические аспекты формирования инвестиционного портфеля предприятия. 214

Нургабылов М.Н., Барлыков Е.К., Егембердиева С.M. Тенденции управления развитием мясоперерабаты-

вающей отрасли в РК.

Нурымбетов Т.Я., Абишова А.У., Уразбаева Г.Ж., Кыдырова Ж.Ш., Байнеева П.Т., Абишов Н.У. Приоритеты

социальной поддержки населения РК в условиях модернизации................................................................................. 22

Рахимова С. А., Тургумбекова М. М. Программы государственной поддержки мсб в республике Казахстан и меры

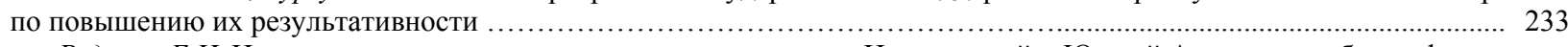

Руденко Е.И. Искаженность восприятия между государствами Центральной и Южной Азии как проблема фактора

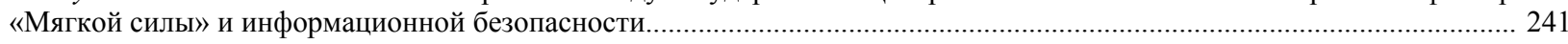

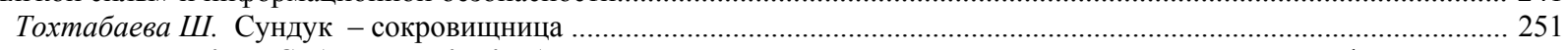

Утепкалиева К.М., Сабирова Р.К., Кенбаева Г.У.Развитие государственно-частного партнерства в нефтегазовой

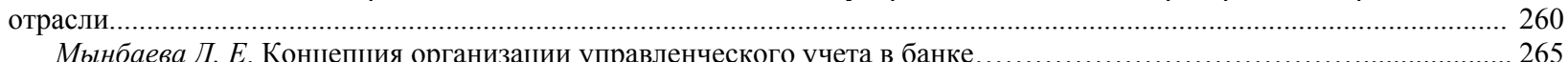

Мынбаева Д. Е. Концепция организации управленческого учета в банке...........................................2.
Султанова Г.С. Педагогические аспекты формирования профессиональных компетенций бакалавра - экономиста

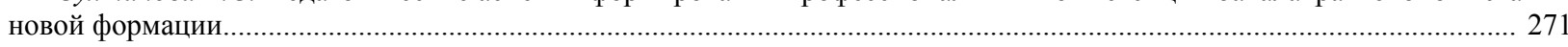

Шаяхметова А.А. О подготовке педагогических кадров к инклюзивному образованию в условиях вуза................ 277 


\section{CONTENTS}

Bespayeva R.S., Bugubayeva R.O., Manuel F. Grela. Formation of the complex strategy for development of the Schuchinsk-

Burabay resort area based on the balanced system of indicators.

Ayupova Z.K., Kussainov D.U., Winston Nagan. Some facets of integration in themodernization ofthe civil process..............13

Kussainova A.A., Kozlowski Waldemar, Gerashchenko I.P. The review of some features of the financial legal mechanism of obligatory social insurance in the republic of Kazakhstan...

Dyussenov B.D. Linguistic features of epigraphic monuments................................................................................ 28

Jumadilova Sh.G., Atabay B.Zh. Dynamics of the population savings in Kazakhstan.......................................................... 33

Karabalina A.A., Alsitova A.B., Kereimaganbetova Zh.N., Abisheva N.M. The values as critical factor of moral education... 42

Kenzhebayeva D.K., Urmurzina B.G., Dashqin Mahammadli. The modern youth values in Kazakhstan............................. 51

Nurmanova A.S., Mederova D.E., Dyussenov B.D. "Bokeykhanov dynasty taldybeyit necropolis" epigraphic monuments

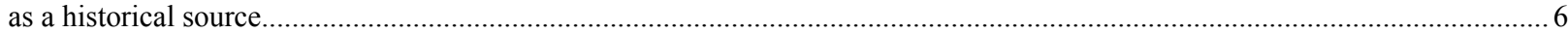

Kydyrova Zh.Sh., Onlasynov E.Z., Abishova A.U., Shadieva A.A.Research of the situation in the market of milk and dairy

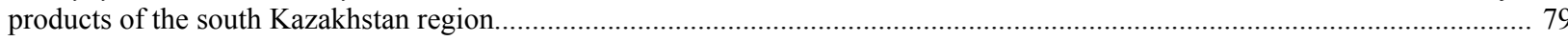

Abishova G.U., Amanzholov R.A., Mynbayeva B.N., Ibragimova D.I. Readiness of students-biologists for the organization

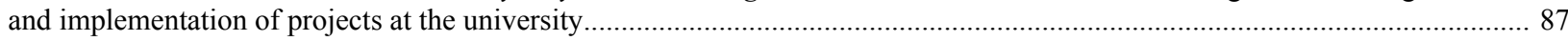

Baltabayeva A.Y., Rizakhojayeva $G$. The phenomenon of the great silk road in the cultural integration process................... 91

Burganova R.I., Abdugalina S.E., Tuyakova A.E. Improving the quality of education through student-centered education... 102

Galiyeva A.Kh., Sadu Zh.N., Kulubekov M.T., Kazbekova L.A. Assessment of the institutional terms of the foreign

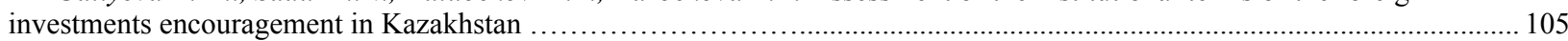

Dzhalilov Z.G. Theoretical discourse on islam and politics in foreign humanism of the second half of 20th century.......... 112

Dzhumabekova A.T., Kanatova A.ZH. Transformation of the transmission mechanism of the national bank of the republic

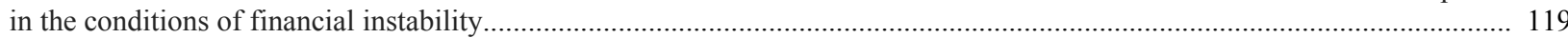

Suleimenov R.B. Problems and features of the development of migration processes in Kazakhstan and Central Asia.......... 124

Yesengulova M.N. Psychological aspects of reintegration and resocialization of "Trouble" adolescents in Kazakhstan....... 134

Zhakisheva K.M., Zhumanova D.T., Mukasheva G.M.The role of monitoring the financial condition of agricultural

enterprises in ensuring sustainable development of the agrarian sector of the economy......................................................... 146

Zhakhina B.B. Principles of functional literacy formation of the kazakh language....................................................... 151

Idresova U.Kh., Saduahasova Z.Zh., Mukhanova A.T. Criminalistics............................................................................. 156

Savelyeva $V . V$. Historicalandpedagogical bases of formation and development of credit technology in Kazakhstan........... 160

Kaliyeva T.M., Sembiyeva L.M. National Resources and national wealth.................................................................. 165

Karimova R., Hajiyeva G. Examining ethno-political and SOCIO-economic transformation of the xinjiang uyghur

autonomous region in the context of the PRC national policies........................................................................................ 176

Kerimbek G., Moldashbayeva L., Jrauova K., Azhmukhamedova A., Misanova A. Analysis and evaluation of reduction

of tax recovery of the republic of kazakhstan on the budget of the republic of Kazakhstan................................................. 185

Zholdasbekova S.A., Parmankulova P.Zh., Assanaliyev M.K. Folk games in the education of children with physical, mental and sensory disturbances..

Moldakenova E.K., Baygabulova K.K., Onaeva B.T. Ways of development of the system of the regional aspect of managing innovative processes in the APC.

Muratova G.K., Shaushenova A.G., Zhumassseitova C.D., Ongarbayeva M.B. Application of cloud technologies in the educational process......

Nurgabylov M.N., Barlikov E.K., Egemberdieva S.M. Trends of management of the development of meat processing industry in RK

Nurymbetov T.Ya., Abishova A.U., Urazbaeva G.Zh., Kydyrova Z.Sh., Baineeva P.T., Abishov N.U. Priorities of social support of the population of republic of Kazakhstan in the conditions of modernization........

Rakhimova S. A., Turgumbekova M. M. Programs of government support for sme in the republic of Kazakhstan and measures to enhance their efficiency.....

Rudenko Ye.I. Misperception between the states of Central and South Asia as a 'Soft power' and information security issue...

Tokhtabayeva Sh. Zh. Treasure-chest.

Utepkalieva K.M., Sabirova R.K., Kenbaeva G.U.Development of public private partnership approach in oil and gas

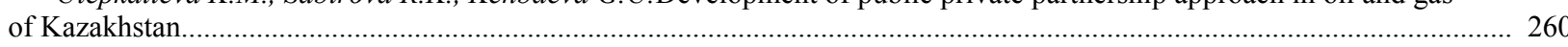

Mynbayeva D.E. Concept of organization of management accounting in bank ........................................................... 265

Sultanova G. S. Pedagogical aspects of formation of professional competence of the bachelor-economist of the new formation

Shayakhmetova A.A. On the training of teaching staff for inclusive education under the conditions of higher education institution. 


\section{PUBLICATION ETHICS AND PUBLICATION MALPRACTICE IN THE JOURNALS OF THE NATIONAL ACADEMY OF SCIENCES OF THE REPUBLIC OF KAZAKHSTAN}

For information on Ethics in publishing and Ethical guidelines for journal publication see http://www.elsevier.com/publishingethics and http://www.elsevier.com/journal-authors/ethics.

Submission of an article to the National Academy of Sciences of the Republic of Kazakhstan implies that the work described has not been published previously (except in the form of an abstract or as part of a published lecture or academic thesis or as an electronic preprint, see $\mathrm{http} / / / \mathrm{www} . e l s e v i e r . c o m / p o s t i n g p o l i c y)$, that it is not under consideration for publication elsewhere, that its publication is approved by all authors and tacitly or explicitly by the responsible authorities where the work was carried out, and that, if accepted, it will not be published elsewhere in the same form, in English or in any other language, including electronically without the written consent of the copyrightholder. In particular, translations into English of papers already published in another language are not accepted.

No other forms of scientific misconduct are allowed, such as plagiarism, falsification, fraudulent data, incorrect interpretation of other works, incorrect citations, etc. The National Academy of Sciences of the Republic of Kazakhstan follows the Code of Conduct of the Committee on Publication Ethics (COPE), and follows the COPE Flowcharts for Resolving Cases of Suspected Misconduct (http://publicationethics.org/files/u2/New_Code.pdf). To verify originality, your article may be checked by the originality detection service Cross Check http://www.elsevier.com/editors/plagdetect.

The authors are obliged to participate in peer review process and be ready to provide corrections, clarifications, retractions and apologies when needed. All authors of a paper should have significantly contributed to the research.

The reviewers should provide objective judgments and should point out relevant published works which are not yet cited. Reviewed articles should be treated confidentially. The reviewers will be chosen in such a way that there is no conflict of interests with respect to the research, the authors and/or the research funders.

The editors have complete responsibility and authority to reject or accept a paper, and they will only accept a paper when reasonably certain. They will preserve anonymity of reviewers and promote publication of corrections, clarifications, retractions and apologies when needed. The acceptance of a paper automatically implies the copyright transfer to the National Academy of sciences of the Republic of Kazakhstan.

The Editorial Board of the National Academy of sciences of the Republic of Kazakhstan will monitor and safeguard publishing ethics. 
Правила оформления статьи для публикации в журнале смотреть на сайте:

\section{www:nauka-nanrk.kz}

\section{social-human.kz}

Редакторы М.С. Ахметова, Т.А. Апендиев, Д.С. Аленов

Верстка на компьютере А.М. Кульгинбаевой

Подписано в печать 08.12.2018

Формат 60x881/8. Бумага офсетная. Печать - ризограф.

17,7 п.л. Тираж 500. Заказ 6.

Национальная академия наук $Р К$

050010, Алматы, ул. Шевченко, 28, т. 272-13-18, 272-13-19 